\title{
Is the Source of FDI Important to Emerging Market Economies? Evidence from Japanese and U.S. FDI
}

\author{
Wi Saeng Kim \\ Hofstra University, U.S.A. \\ Esmeralda Lyn \\ Hofstra University, U.S.A. \\ Edward Zychowicz \\ Hofstra University, U.S.A.
}

This paper takes the position that technology transfers associated with foreign direct investment inflows (FDI) are an important determinant of economic growth in developing countries. The paper also posits that technology transfers, ceteris paribus, depend on the attributes of FDI providers, particularly as they relate to the degree of technological advancement and the behavioral aspects of the technology transfer. Japan and the U.S. are two important sources of FDI where multinational corporations domiciled in the two nations exhibit distinct variation in these attributes. Consistent with earlier research, the findings of this paper lend support for a positive role of FDI inflows from the advanced countries in increasing the economic growth of developing countries. The paper further finds some evidence that the relationship between the economic growth of the host countries and FDI inflows is stronger for U.S. originated FDI than that of Japanese originated FDI. This finding is consistent with the notion that U.S. multinational firms are more effective in generating technology transfers and spillovers to developing countries than do Japanese multinational firms (JEL F210, F430, O000).

Keywords: emerging market economies, foreign direct investments, economic development, technology transfer.

\footnotetext{
* The authors thank the referees and the editors for their useful comments and suggestions.
}

(Multinational Finance Journal, 2003, vol. 7, no. 3 \& 4, pp. 107-130)

(C) Multinational Finance Society, a nonprofit corporation. All rights reserved. DOI: $10.17578 / 7-3 / 4-1$ 


\section{Introduction}

The "new growth" theory developed by Romer (1986, 1990) and Rivera-Batiz and Romer (1991) offers an alternative explanation for productivity and output growth and claims that technological change lies at the heart of economic growth. ${ }^{1}$ The technological change provides the incentive for continued capital accumulation, and together, capital accumulation and technological change account for much of the increase in labor productivity of the OECD member nations. Howitt (2000) recently extended the new growth theory to a multi-country framework and shows that per capita income varies across countries not only because of differences in capital stock per worker but also because of differences in productivity. He further demonstrates that the developing countries that engage in $R \& D$ will continue to grow and will be able to catch up with the advanced countries.

Levine and Renelt (1992) also assert that much of the cross-national differences in the economic growth rates of advanced economies are accounted for by differences in research and development (R\&D) activities. Rivera-Batiz and Romer (1991) suggest that the economic growth rates of developing countries will benefit from the international transmission of ideas and economic integration. Barro and Sali-I-Martin (1995) and Eaton and Kortum (1996) also imply that cross-national technology transfers will facilitate the convergence of country economic growth rates in the long run. More specifically, Bernstein and Mohenen (1998), Coe and Helpman (1995), and Hegazi and Safarian (1999) assert that foreign direct investment (FDI) inflows from advanced economies function as a conduit for the transfer of technology, which in turn will improve the economic growth rates of developing countries. This issue is therefore critical because, as Hegazi and Safarian (1999) point out, developing countries are not extensively or significantly involved in domestic R\&D activities.

Therefore, $R \& D$ transfers from advanced countries are considered as a proxy for domestic R\&D activities, where such activities are viewed as one important and endogenous determinant of economic

1. Neoclassical growth models developed earlier by Solow (1956) and Cass (1965) have formed the basis of the intuitive view that the rate of return on investment and the rate of growth of per capita output are expected to be decreasing functions of the level of capital stock. A country's per capita growth rate tends to be inversely related to its starting level of income per capita and thus, levels of per capita income will converge over time across countries. 
growth for these countries. This paper posits that, to the extent that FDI inflows from advanced countries serve as conduit of technology transfers, the economic growth rates of developing countries will be positively affected by the FDI inflows from advanced countries.

The main objective of this paper is to assess whether FDI inflows from advanced countries contribute to the explanation of cross-national differences in the growth of economic output of developing countries. FDI inflows from advanced countries are regarded as a proxy for the R\&D level of developing countries, which within the framework of implications originating with the new growth theory, is the fountainhead of economic growth. The paper is organized as follows. Section II presents the framework used to analyze the relationship between the growth in economic output of the FDI receiving countries and the technological variation among different FDI providers. Section III presents the econometric models and a description of the data. Section IV presents the test results and section $\mathrm{V}$ the conclusions.

\section{Emerging Market Economies and FDI Inflows}

As developing countries are not significantly engaged in the development of new technologies, the technology level of developing countries is far below the level of technology embedded in the most advanced types of capital (Hegazi and Safarian [1999]). The most sophisticated technology, which is a characteristic of the most highly advanced form of capital available in the world, is conceptualized as being located on the 'world technology frontier' (see for example Jones [1998]). Emerging market countries, however, can obtain sophisticated technologies when advanced capital goods are introduced by MNCs from developed countries (Bernstein and Mohenen (1998), Coe and Helpman (1995), and Hegazi and Safarian [1999]). The inflow of advanced capital goods will move the recipient country's technology level closer to world technology frontier. In other words, as they receive FDI inflows from more advanced countries, their domestically available technology level will be augmented with foreign capital represented by the higher technology. This will improve labor productivity of FDI recipient countries, and consequently, will increase the economy's potential to generate greater output.

Based on the following specification by Perez (1998) and Coe and Helpman (1995), the accumulation of FDI inflows, which is the foreign 
direct investment stock, is used as a proxy for the transfer of technology, and the developing country's production function is expressed as follows:

$$
Y=\psi\left(K_{f} / H\right) G\left(K_{f}+K_{d}, H\right)
$$

where

$Y$ is output of all firms in the country

$H$ is stock of human capital

$$
K_{d}=\int_{0}^{A D} x(i) d i \text { is the capital stock, } x(i) \text {, of domestic firms, where }
$$

$i$ represents the domestic capital goods type from the most basic to the most technologically advanced type, $A D$,

$$
K_{f}=\int_{A D}^{A F} x(i) d i \text { is the capital stock of foreign firms, where } A F
$$

represents the most technologically advanced foreign capital goods type and

$\psi\left(K_{f} / H\right)$ is a function representing technology transfers from FDI providers, where it is assumed to have a value greater than one for $\left(K_{f} / H\right)>0$.

To the extent that the relative technology levels are represented by $K_{f}-$ $K_{d}>0$, the FDI receiving countries employ more advanced capital equipment. This means, that $\partial G / \partial K_{f}>\partial G / \partial K_{d}$. Therefore, the change in FDI, i.e. the FDI inflows, will generate greater economic output than domestic capital investments. Moreover, the inflow of FDI provides technological transfers and spillovers to recipient countries. Technological spillovers are related to FDI as represented by $K_{f}$, therefore we have

$$
\frac{\partial \psi}{\partial K_{f}}>0
$$


The marginal returns to domestic capital goods are derived by differentiating equation (2) by $K_{d}$

$$
M R_{d}=\frac{\partial Y}{\partial K_{d}}=\psi G_{k}
$$

The marginal returns to capital goods obtained through FDI inflows are derived by differentiating equation (2) by $K_{f}$

$$
M R_{f}=\frac{\partial Y}{\partial K_{f}}=\frac{\partial \psi}{\partial K_{f}} G+\psi G_{K}
$$

Equations (3) and (4) show that $M R_{f}>M R_{d}$. The term $\left(\partial \psi / \partial K_{f}\right) G$ in equation (4) is a measure of technology improvements induced by the transfers and spillovers related to FDI from countries with higher technology levels. Within this framework, $\left(\partial \psi / \partial K_{f}\right) G$ has the nature of a public good, whereas the private marginal return to both foreign and domestic capital is $\psi G_{K}$.

The preceding framework has three implications. First, the productivity improvements caused by FDI inflows from advanced economies are greater than those caused by domestic capital formation because $A D<A F$. Second, the technology transfers and spillovers measured by $\left(\partial \psi / \partial K_{f}\right) G$ will be higher when the proportion of a country's total capital stock comprised of foreign direct investment from the advanced countries is higher. This implies that economies will grow with increases in FDI inflows. Moreover, it is also predicted that the closer these foreign capital goods are to the world technology frontier, the more potent will be the technological transfer effects of FDI and, consequently, the economic growth effects of FDI.

To the extent that FDI brings in more advanced types of foreign capital goods that are closer to the world technology frontier, the new growth model articulated by Romer (1990), Rivera-Batiz and Romer (1991), Coe and Helpman (1995), and Jones (1998) implies that FDI inflows increase the marginal product of capital investment and labor productivity via technology transfers and spillovers.

Differences in Japanese and U.S. FDI in Emerging Market Economies The global economy has experienced a dramatic surge in foreign direct investment (FDI) activity in recent decades and developing economies 
have become a major destination of world FDI outflow. ${ }^{2}$ Many developing countries see FDI as a key element of their development strategies. As presented in the previous section, FDI inflows from advanced countries promote capital formation, and in addition, function as a vehicle for the transfer of technology and managerial practices that create growth-promoting efficiencies in the recipient economies. This study proposes that the extent of the positive impact of FDI inflows on the output of recipient economies vary with the identities of FDI providing nations because multinational corporations, MNCs, which are firms investing in de novo investments in other countries, may have different motives for FDI. In fact, the extant literature is rich in explaining why the motives for FDI by U.S. MNCs differ from those of Japanese MNCs. ${ }^{3}$

A number of researchers contend that the Japanese FDI model is different from the American model because Japanese MNCs do not necessarily possess firm-specific intangible assets. Ozawa(1972) states that Japanese firms invest abroad not to seek monopolistic rent by internalizing monopolistic advantages they possess, but rather to seek low-cost-labor or other production factors such as natural resources. ${ }^{4}$

Recent studies by Blonigen (1997), Caves and Mehra (1986), and Kogut and Chang (1991) conclude that the motive of Japanese FDI in the U.S. was to seek R\&D related firm-specific assets in America. Eaton and Kortum (1996) show that technology spillover exists from the

2. As recently as 1990, only 15 percent of all FDI flowed to developing nations. In 1997 this figure was approximately 40 percent. See, for example, A World Bank Policy Research Report (1997).

3. Traditional theories of FDI explaining the motives for FDI make the common assertion that U.S.-based MNCs possess rent-yielding firm-specific intangible assets. The monopolistic advantage theory, for example, argues that MNCs obtain rent-yielding firm-specific assets that local competitors do not have, which enables the MNCs to compete successfully with local firms. The internalization theory postulates that FDI occurs when a firm can maximize its value by internally employing its rent-yielding intangible assets, rather than by licensing the technology to foreign producers. Hymer (1976) and Caves (1971) explains that MNCs tend to invest heavily in R\&D, which will generate monopolistic rent. The product life cycle theory of Vernon (1966) states that new products will be introduced in advanced economies because of technological know-how and demand for new products. But as production know-how becomes standardized over time, the production location moves from advanced economies to lower labor cost economies.

4. The Japanese government adopts industrial policies to encourage the growth of certain industries that government officials find merit, and the exit from environmentally deteriorating industries. Firms in the latter industries will get assistance from the government to invest abroad. 
United States to Japan, but not in reverse direction. The authors indicate that U.S. R\&D spillover account for over $40 \%$ of Japan's productivity growth.

The preceding literature provides strong indication that Japanese MNCs do not possess the R\&D based firm-specific intangible assets in comparison to U.S. MNCs, which imply the following:

$$
K_{U S}=\int_{0}^{A F U S} x(i) d i \text { and } K_{J P}=\int_{0}^{A F J P} x(i) d i
$$

where AFUS represents the most advanced U.S. technology and AFJP the most advanced Japanese technology. The inequality $K_{U S}>K_{J P}$ implies that the technology level of capital goods that Japanese FDI brings in is lower than that of U.S. FDI. Within the framework of equation (4), we predict

$$
\left[\psi G_{K f}+\left(\partial \psi / \partial K_{f}\right) G\right]_{U S A}>\left[\psi G_{K f}+\left(\partial \psi / \partial K_{f}\right) G\right]_{J a p a n}
$$

Therefore, the potential for Japanese FDI to function as a vehicle that augments the capability of the host economy to grow is less effective compared to U.S. FDI.

The scope for productivity improvements of human capital associated with technological transfers can also depend on the attributes of FDI providers. To the extent that the motives of Japanese MNCs are to acquire cheap labor found in the host economies, rather than to apply advanced technologies in recipient countries, Japanese FDI will be labor-intensive relative to U.S. MNCs. Given that the U.S.-originated FDI is closer to the world technology frontier (AW) than Japanese originated FDI, the U.S. FDI should have a stronger impact on skill accumulation (technology transfers) in the recipient country. ${ }^{5}$

Additionally, technology transfers from FDI as reflected in the term $\left(\partial \psi / \partial K_{f}\right) G$ could also embody behavioral factors impacting the dissemination of technology to the local workers. According to Urata (1996), the means of technology transfer to the host economies differ between Japanese MNCs and their Western counterparts. Local workers

5. See Jones (1998) and Hall and Jones (1999) for a model that explains the growth in human capital. 
in Japanese MNCs acquire technology through on-the-job training, while those working in Western MNCs acquire technology with the help of manuals. To the extent that manuals are available to a greater number of workers than the case of on-the-job training, the rate of technology transfer to host economies will be faster for the former method than the latter method. Furthermore, Sedgwick (1996) reports that Japanese MNCs tend to hold back technology transfers to the host economies. This suggests that the FDI originating in Japan will engender less output-enhancing technology transfers to recipient economies compared with the impact of FDI that originates from the US.

\section{Empirical Tests}

In this section, the implications developed above and depicted by equation (4) are tested, foremost among these being that economic growth in developing countries depends not only on human capital and domestic capital investments, but also on the technology transfer they receive from foreign direct investment inflows. More specifically, this study tests whether technology transfer, ceteris paribus, depends on the attributes of FDI providers, particularly as they relate to the degree of technological advancement and the behavioral aspects of the technology transfer, as shown in equation (5). This test is accomplished by looking at the impact on economic growth of FDI from two important and advanced FDI providers, Japan and the U.S., where multinational corporations domiciled in the two nations exhibit distinct variation in these attributes. This study also controls for financial development and country risk measures. To this end, primary and secondary data are obtained from a number of sources.

\section{A. Regression Models}

The intent of the regression model specifications is to empirically test the three implications of the conceptual framework developed in the previous section. Recall, it is predicted that (1) foreign investment will have a more potent impact on economic growth compared to domestic investment, (2) the larger the proportion of foreign investment relative to total investment within the recipient country the greater the impact on economic growth, and (3) foreign investment will have stronger effect on economic growth when the capital goods brought into a recipient 
country are more advanced (i.e. closer to the world technology frontier).

Consistent with the model specifications developed in studies such as those by Borensztein et al. (1998) and Stiroh (2001), the following two regression models, (6) and (7), are used to test the first prediction, namely that foreign investment will make a greater contribution to economic growth than domestic investment undertaken in the host economy.

$$
G R_{i, t}=c_{0}+c_{1} F D I_{i, t}+c_{2} H C_{i, t}+c_{3} D O M I_{i, t}+e_{i, t}
$$

where $G R_{i, t}$ is the growth rate of real GDP for the $i$ th recipient country in year $t . F D I_{i, t}$ is the total foreign direct investment inflows relative to GDP for the $i$ th recipient country in year $t . H C_{i, t}$ is a proxy for the stock of human capital measured by the literacy rate. $D O M I_{i, t}$ is the domestic capital investment relative to GDP for the ith country in year t. FDI and $H C$ are expected to have a positive impact on economic growth. As implied in equation (4) and also posited by Borensztein et al. (1998), $F D I$ inflow is expected to have a greater impact on economic growth of emerging markets than domestic capital investment, DOMI.

Including the control variables for financial development and country risk measures, the regression model takes the form:

$$
\begin{gathered}
G R_{i, t}=c_{0}+c_{1} F D I_{i, t}+c_{2} H_{i, t}+c_{3} \text { DOMI }_{i, t}+c_{4} \text { CRISK }_{i, t} \\
+c_{5} \text { FINDEV }_{i, t}+c_{6} \text { TURN }_{i, t}+e_{i, t}
\end{gathered}
$$

The last three variables capture the characteristics of the recipient country's risk and financial market infrastructure. Given the importance of country risks in emerging market investment decisions (see, for example, Clark and Tanaru [2001]), we include the variable $C_{R I S K_{i, t}}$ which is the International Country Risk Guide's (ICRG) composite variable measuring the political, economic and financial risk of a particular country. The variable can take on a maximum value of 100 . The higher the magnitude of $C R I S K_{i, t}$, the lower the degree of composite risk, and therefore, the lower the risk of the country. Therefore, a positive relationship between economic growth and $C_{R I S K_{i, t}}$ is expected.

FINDEV $V_{i, t}$ measures the market capitalization relative to GDP for recipient country i in year t. Atje and Jovanovic (1993) find that stock 
markets have a larger impact on economic development than the impact of bank lending. Levine and Zervos (1994) assert that larger stock markets have a greater capability to promote economic growth because there is greater scope to "mobilize capital and diversify risk on an economy-wide basis." Beck, Levine, and Loayza (2000) find that the level of financial intermediary development exerts a large positive impact on overall GDP growth. $T U R N_{i, t}$, measured by the value of total shares traded divided by market capitalization, is a proxy for the liquidity of the stock market. Levine and Zervos (1994) suggest that a higher turnover ratio, $\left(T U R N_{i, t}\right)$, indicate lower transaction costs. Furthermore, Levine (1997) finds a positive relationship between measures of liquidity and economic growth. $T U R N_{i, t}$ is expected to be positively related to economic output.

The second implication of the theoretical framework predicts that as the proportion of total investment represented by foreign investment increases, then the impact on economic growth will be greater. From equations (3) and (4), it is shown that the technology transfers and spillovers measured by $\left(\partial \psi / K_{f}\right) G$ will be higher when the proportion of a country's total capital stock is comprised of foreign direct investment from the advanced countries is higher. Therefore, to capture more effectively the impact of FDI on economic growth, $F D I_{i, t}$ is replaced with $F D I C F_{i, t}$, which is the annual foreign direct investment inflow of the $i$ th country in year $t$ divided by the total capital formation for the $i$ th country in year $t$. The total capital formation includes domestic capital formation and foreign direct investment. Thus, regression model specifications (8) and (9) test the second prediction.

$$
G R_{i, t}=c_{0}+c_{1} F D I C F_{i, t}+c_{2} H C_{i, t}+e_{i, t}
$$

and

$$
\begin{aligned}
G R_{i, t}= & c_{0}+c_{1} \text { FDICF }_{i, t}+c_{2} \text { HC }_{i, t}+c_{3} \text { CRISK }_{i, t}+ \\
& +c_{4} \text { FINDEV }_{i, t}+c_{5} \text { TURN }_{i, t}+e_{i, t}
\end{aligned}
$$

The new growth theory as shown in equation (5) implies that the closer the foreign capital goods to the world technology frontier, the more potent will be the technological transfer effects of FDI and the greater the effect on economic growth. The extant literature on FDI suggests that the motives for FDI by U.S. MNCs differ from those by Japanese MNCs, and that U.S. MNCs possess rent-yielding 
firm-specific intangible assets, while Japanese MNCs do not. This suggests that the technology level of capital goods that Japanese FDI brings in is lower than that of U.S. FDI. Regression models (10) and (11) are used to empirically ascertain the differential impact on economic growth attributable to FDI originating in Japan and in the U.S., respectively.

$$
\begin{aligned}
G_{i, t}= & c_{0}+c_{1} \operatorname{JPFDI}_{i, t}+c_{2} \operatorname{USFDI}_{i, t}+c_{3} \mathrm{HC}_{i, t}+c_{4} \text { DOMI }_{i, i} \\
& +c_{5} \text { CRISK }_{i, t}+c_{6} \text { FINDEV }_{i, t}+c_{7} \text { TURN }_{i, t}+e_{i, t}
\end{aligned}
$$

where the variable JPFDI reflects the FDI inflow to a recipient country from Japan divided by GDP. The variable USFDI reflects the FDI inflow to a recipient country from the United States divided by GDP. It is expected that USFDI will have a larger coefficient than JPFDI.

In order to capture more effectively the impact of FDI from the two providers on economic growth, $J P F D I_{i, t}$ is replaced with $J P F D I C F_{i, t}$, and $U S F D I_{i, t}$ is replaced with $U S F D I C F_{i, t}$. The variable $J P F D I C F_{i, t}$ in regression model (11) reflects the FDI inflow to a recipient country from Japan divided by total capital formation. The variable $U S F D I C F_{i, t}$ reflects the FDI inflow to a recipient country from the United States divided by total capital formation. The total capital formation includes domestic capital formation and foreign direct investment. It is expected that USFDICF will have a larger coefficient than JPFDICF. Regression model (11), which is used to empirically ascertain the differential impact on economic growth attributable to FDI originating in Japan and in the US, will take the form:

$$
\begin{gathered}
G R_{i, t}=c_{0}+c_{1} \text { JPFDICF }_{i, t}+c_{2} \text { USFDICF }_{i, t}+c_{3} H C_{i, t} \\
+c_{4} \text { CRISK }_{i, i}+c_{5} \text { FINDEV }_{i, t}+c_{6} \text { TURN }_{i, t}+e_{i, t}
\end{gathered}
$$

\section{B. The Data}

Annual levels of GDP and measures of per capita GDP are obtained from the 1998 OECD Geographical Distribution of Financial Flow to Aid Recipients, and annual real GDP growth rates come from the 2001 IMF World Economic Outlook Database. The OECD source provides 
measures of FDI that represent total private direct investment flowing into respective recipient emerging market economies from the advanced national economies comprising the OECD's Development Assistance Committee (DAC). Measures of FDI emanating from the United States and going to each of the emerging markets are provided by the U.S. Department of Commerce, while FDI originating from Japan were obtained from Japan's Ministry of Finance. Measures of total and domestic capital formation come from various issues of the UNCTAD World Investment Report. Literacy rates are found on the OECD database and are used as a proxy for a country's stock of human capital accumulated through education, as in Levine and Renelt (1992).

The model employed in this study also controls for financial development in the emerging countries by using stock market capitalization and value traded measures from the IFC Emerging Markets Data Base. The model also controls for political, economic and financial risk factors by employing both individual and composite measures of these three risk factors published in the Political Risk Services International Country Risk Guide (ICRG). (See appendix 1 which contains an overview of the methodology used to produce the ICRG composite risk index.). The final sample consists of 26 emerging market countries with data for all the required variables needed for the regression models over the time period 1989 through 1997. These 26 countries are further classified by the World Bank (1997) as belonging to categories 1 to 4 where 1 is assigned to the highest income countries within the emerging countries group. (See appendix 2 for the list of countries and respective World Bank categories).

\section{Discussions of the Test Results}

Using standard panel data methodology, a fixed effects model is used to conduct all the empirical analyses of the panel data. The methodology has the advantage of controlling for omitted country specific factors that vary across countries, as well as for time effects that are common to all countries, and thus will mitigate the effects of eventual measurement errors when using panel data. Specifically, equations (6) to (11) are operationalized using a two-way fixed effects model for panel data (see Greene [2000] and Matyas and Sevestre [1992]): 
TABLE 1. Descriptive Statistics for the Whole Sample 1989-97

\begin{tabular}{lcccc}
\hline Variables & Mean & Minimum & Maximum & $\begin{array}{c}\text { Standard } \\
\text { Deviation }\end{array}$ \\
\hline$G$ & 3,261 & 210 & 15,900 & 3,440 \\
$H C$ & .80 & .21 & .98 & .17 \\
FDI & 3,216 & 3 & 44,237 & 6,498 \\
JPFDI & .003 & 0 & .021 & .004 \\
USFDI & .006 & 0 & .092 & .010 \\
DOMI & .226 & .026 & .567 & .087 \\
FDICF & .091 & .001 & .417 & .084 \\
JPFDICF & .010 & .0001 & .080 & .015 \\
USFDICF & .029 & .0003 & .416 & .047 \\
CRISK & 67.3 & 37.5 & 87.0 & 9.5 \\
PRSK & 63.8 & 31.0 & 83.0 & 10.1 \\
FRSK & 36.6 & 16.0 & 49.0 & 6.8 \\
ERSK & 34.0 & 18.0 & 44.5 & 5.2 \\
TURN & .524 & .005 & 7.1 & .774 \\
FINDEV & .434 & .005 & 3.7 & .571 \\
Number of Countries: & 26 & & & \\
\hline
\end{tabular}

Note: $G$ is GDP per capita, $H C$ is a measure of literacy rate, FDI is total inward FDI inflows (in thousands of \$), JPFDI is the ratio of Japanese FDI inflow to GDP of host country, USFDI is the ratio of U.S. FDI inflow to GDP of host country, DOMI is the ratio of domestic capital formation to GDP, FDICF is the ratio of total FDI to total capital formation, $J P F D I C F$ is the ratio of Japanese FDI to total capital formation, USFDICF is the ratio of U.S. FDI to total capital formation, CRISK is a measure of country risk (out of 100 points) of host country, PRSK is a measure of political risk (out of 100 points) of host country, FRSK is a measure of financial risk of host country, ERSK is a measure of economic risk (out of 50 points) of host country, TURN is a market liquidity measure of host country, and FINDEV is a financial development measure. data sources: per capita GDP, FDI, and literacy rates are obtained from the 1998 OECD Geographical Distribution of Financial Flow to Aid Recipients. USFDI measures are provided by the U.S. Department of Commerce, while JPFDI data are obtained from Japan's Ministry of Finance. DOMI and FDICF come from various issues of the UNCTAD World Investment Report. TURN and FINDEV are from the IFC Emerging Markets Data Base. The four risk measures are obtained from the Political Risk Services International Country Risk Guide (ICRG).

$$
G_{i, t}=\mu+\alpha_{i}+\delta_{t}+\gamma_{i} \sum x_{i, t}+\varepsilon_{i, t}
$$

where $a_{i}$ is a country-specific intercept to reflect country factors that may produce cross-sectional variation in the measures of the independent variables; while $\delta_{t}$ captures the fixed effects in individual time periods that would produce correlation in the cross-sectional components of the error term. $\mu$ is the overall constant. $\gamma_{i} \Sigma x_{i, t}$ reflects 
the explanatory variables and their respective coefficients, whereby the coefficients and parameter estimates have the same interpretation as in the OLS methodology.

Table 1 presents the descriptive statistics for the entire sample. As the table shows, the sample of 26 countries is a heterogeneous group with a mean per capita GDP of $\$ 3,261$ and a median of $\$ 2,290$. The mean of the literacy rate is $80 \%$ with a standard deviation of $17 \%$. U.S. FDI inflow as a proportion of recipient country GDP (USFDI), $0.6 \%$, is twice as large as Japanese FDI inflow as a ratio of recipient country GDP (JPFDI), which is $0.3 \%$. U.S. FDI inflow as a proportion of recipient country total capital formation (USFDICF), $2.9 \%$, is almost three times as large as that of Japanese FDI inflow (JPFDICF), which is $1 \%$. The sample countries are considered moderately risky as shown by the mean country risk measure, CRISK, of 67.3 points with a standard deviation of 9.5 points. (See appendix 1 for risk guidelines). The measures of financial development, FINDEV, and market liquidity, TURN, vary widely among the sample firms, as shown by the large standard deviations.

Table 2 partitions the sample into two groups based on the classification of countries by the World Bank in 1997. High income countries are classified by the World Bank as belonging to either category 1 or 2, while low income countries belong to either category 3 or 4 , as shown in appendix 2 . The table shows that, in high income countries, U.S. FDI is .7\% of GDP (USFDI) and 3.5\% of total capital formation (USFDIFC), while Japanese FDI is .2\% of GDP (JPFDI) and $.8 \%$ of total capital formation (JPFDIFC). For low income countries, U.S. FDI is .5\% of GDP (USFDI) and $2.2 \%$ of total capital formation (USFDIFC), while Japanese FDI is .3\% of GDP (JPFDI) and $1.2 \%$ of total capital formation (JPFDIFC). These indicate that Japanese FDI is more concentrated in low income countries.

Table 2 also exhibits that, as expected, the high income group has higher literacy rate, lower country risk, and more developed financial markets than the low income group. In fact, the high income group with a mean of 72.2 points for $C R S K$, falls under the low risk group according to the risk guidelines in appendix 1 . The measures of financial development, FINDEV, and market liquidity, TURN, vary widely among the countries in each income category, although more so in the high income group, as shown by the large standard deviations.

Table 3 reports the regression results where the dependent variable is the real growth rate of GDP and the independent variables include 
TABLE 2. Descriptive Statistics Low Income Group vs. High Income Group

\begin{tabular}{lccccc}
\hline & \multicolumn{2}{c}{ Low Income } & & & \multicolumn{2}{l}{ High Income } \\
\cline { 2 - 3 } \cline { 5 - 6 } Variables & Mean & $\begin{array}{c}\text { Standard } \\
\text { Deviation }\end{array}$ & & Mean & $\begin{array}{c}\text { Standard } \\
\text { Deviation }\end{array}$ \\
\hline GG & 1,192 & 811 & & 5,642 & 3,783 \\
HC & .740 & .197 & & .874 & .092 \\
FDI & 3,279 & 8,316 & 3,183 & 3,474 \\
JPFDI & .003 & .004 & .002 & .004 \\
USFDI & .005 & .013 & .007 & .007 \\
DOMI & .239 & .087 & .212 & .086 \\
FDICF & .079 & .074 & .105 & .095 \\
JPFDICF & .012 & .015 & .008 & .014 \\
USFDICF & .022 & .056 & .035 & .034 \\
CRISK & 63.1 & 9.1 & 72.2 & 7.5 \\
PRSK & 58.2 & 9.8 & & 70.1 & 5.9 \\
FRSK & 34.4 & 6.7 & 39.3 & 5.8 \\
ERSK & 33.4 & 4.4 & 34.8 & 5.9 \\
TURN & .430 & .506 & .637 & .993 \\
FINDEV & .259 & .238 & .642 & .750 \\
Number of countries & 15 & & 11 & \\
\hline
\end{tabular}

Note: See table 1 for the definitions of variables and data sources. Low income countries are classified by the World Bank as belonging to either category 3 or 4 , while high income countries belong to either category 1 or 2 . See appendix 2 for list of countries.

FDI inflows from all sources along with the control variables discussed earlier. Regression 3.1 shows that coefficients for both FDI and human capital, $H C$, are not statistically significant but that the coefficient of domestic capital formation (DOMI) is negative and statistically significant at the 1 percent level. Regression 3.2 indicates that the composite risk variable CRISK is a significant positive factor in explaining economic growth. When the composite risk measure, CRISK, is decomposed into its three categories in regression 3.3, only economic risk, ERSK, has a positive and significant coefficient at the $1 \%$ level.

Table 3 also reports the model specifications which measure the impact of FDI and domestic capital formation by utilizing the ratio of FDI inflow to the total capital formation of the recipient country, FDICF. Total capital formation includes domestic capital formation and foreign direct investment. As regressions 3.4 and 3.5 show, the coefficients of FDICF are positive and statistically significant at the $1 \%$ level. These results lend support to the implication of the conceptual 
TABLE 3. Relationship of the Real Growth Rate of GDP, FDI Inflows and Other Explanatory Variables

\begin{tabular}{|c|c|c|c|c|c|}
\hline \multirow[b]{2}{*}{ Variables } & \multicolumn{5}{|c|}{ Regressions (t-statistics in parentheses) } \\
\hline & 3.1 & 3.2 & 3.3 & 3.4 & 3.5 \\
\hline Intercept & $\begin{array}{c}0.025 \\
(0.22)\end{array}$ & $\begin{array}{l}-0.060 \\
(-0.46)\end{array}$ & $\begin{array}{l}-0.145 \\
(-1.08)\end{array}$ & $\begin{array}{l}0.076 \\
(0.79)\end{array}$ & $\begin{array}{l}-0.019 \\
(-0.18)\end{array}$ \\
\hline$F D I$ & $\begin{array}{c}0.005 \\
(1.14)\end{array}$ & $\begin{array}{l}0.004 \\
(0.80)\end{array}$ & $\begin{array}{l}0.005 \\
(1.08)\end{array}$ & & \\
\hline$F D I C F$ & & & & $\begin{array}{l}0.125 \\
(2.65)^{* * *}\end{array}$ & $\begin{array}{c}0.122 \\
(2.61)^{* * *}\end{array}$ \\
\hline$H C$ & $\begin{array}{l}-0.021 \\
(-0.18)\end{array}$ & $\begin{array}{l}-0.005 \\
(-0.05)\end{array}$ & $\begin{array}{c}0.072 \\
(0.57)\end{array}$ & $\begin{array}{l}-0.044 \\
(-0.38)\end{array}$ & \\
\hline DOMI & $\begin{array}{l}-0.028 \\
(-3.10)^{* * * *}\end{array}$ & $\begin{array}{l}-0.026 \\
(-2.86)^{* * * *}\end{array}$ & $\begin{array}{c}-0.028 \\
(-2.99)^{* * *}\end{array}$ & & \\
\hline CRISK & & $\begin{array}{c}0.001 \\
(1.68)^{*}\end{array}$ & & & 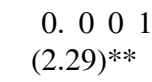 \\
\hline PRSK & & & $\begin{array}{l}-0.000 \\
(-0.16)\end{array}$ & & \\
\hline FRSK & & & $\begin{array}{c}0.000 \\
(0.43)\end{array}$ & & \\
\hline ERSK & & & $\begin{array}{l}0.002 \\
(2.56)^{* * *}\end{array}$ & & \\
\hline$T U R N$ & & $\begin{array}{l}-0.002 \\
(-0.47)\end{array}$ & $\begin{array}{l}-0.002 \\
(-0.41)\end{array}$ & & $\begin{array}{l}-0.002 \\
(-0.37)\end{array}$ \\
\hline FINDEV & & $\begin{array}{c}0.008 \\
(0.84)\end{array}$ & $\begin{array}{c}0.005 \\
(0.55)\end{array}$ & & 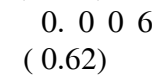 \\
\hline R-squared & 0.472 & 0.490 & 0.508 & 0.457 & 0.483 \\
\hline F-value & $3.02 * * *$ & $2.63 * * *$ & $2.03 * * *$ & $3.14 * * *$ & $2.67 * * *$ \\
\hline \# of cross-sections & 26 & 26 & 26 & 26 & 26 \\
\hline \# of time-series & 9 & 9 & 9 & 9 & 9 \\
\hline
\end{tabular}

Note: $* * *$ denotes $1 \%$ significance level,**denotes $5 \%$ significance level, and $*$ denotes $10 \%$ significance level. FDI is the log of the ratio of FDI to GDP, $H C$ is the literacy rate (\%) as a measure of stock of human capital, DOMI is the log of the ratio of domestic capital formation to GDP, FDICF is the annual foreign direct investment inflow divided by the total capital formation which includes domestic capital formation and foreign direct investment, CRISK is for country risk of host country (out of 100 points), $P R S K$ is for political risk of host country (out of 100 points), PRISK is for financial risk of host country (out of 50 points), ERSK is for economic risk of host country (out of 100 points), and FINDEV is a market liquidity measure and TURN is a financial development measure.

framework developed in section II that the larger the proportion of foreign investment relative to total investment within the recipient 
TABLE 4. Relationship of Real Growth Rate of GDP, Country Sources of FDI Inflows and Other Explanatory Variables

\begin{tabular}{|c|c|c|c|c|}
\hline \multirow[b]{2}{*}{ Variables } & \multicolumn{4}{|c|}{ Regressions (t-statistics in parentheses) } \\
\hline & 4.1 & 4.2 & 4.3 & 4.4 \\
\hline \multirow[t]{2}{*}{ Intercept } & 0.047 & -0.027 & -0.118 & 0.013 \\
\hline & $(0.41)$ & $(-0.21)$ & $(-0.89)$ & $(0.13)$ \\
\hline \multirow[t]{2}{*}{$J P F D I$} & 0.004 & 0.003 & 1.593 & \\
\hline & $(1.36)$ & $(1.20)$ & $(0.11)$ & \\
\hline \multirow[t]{2}{*}{ USFDI } & 0.007 & 1.605 & 0.006 & \\
\hline & $(2.09)^{* *}$ & $(0.11)$ & $(1.76)^{*}$ & \\
\hline \multicolumn{5}{|l|}{$J P F D I C F$} \\
\hline & & & & $\begin{array}{c}0.294 \\
(1.03)\end{array}$ \\
\hline USFDICF & & & & $\begin{array}{c}0.142 \\
(1.66)^{*}\end{array}$ \\
\hline \multirow[t]{2}{*}{$H C$} & -0.002 & 0.010 & 0.095 & -0.037 \\
\hline & $(-0.02)$ & $(0.08)$ & $(0.77)$ & $(-0.30)$ \\
\hline DOMI & $\begin{array}{l}-0.028 \\
(-3.10)^{* * *}\end{array}$ & $\begin{array}{l}-0.026 \\
(-2.88)^{* * * *}\end{array}$ & $\begin{array}{l}-0.029 \\
(-3.10)^{* * *}\end{array}$ & \\
\hline CRISK & & $\begin{array}{c}0.001 \\
(1.39)\end{array}$ & & $\begin{array}{c}0.001 \\
(1.75)^{*}\end{array}$ \\
\hline PRSK & & & $\begin{array}{c}-0.000 \\
(-.24)\end{array}$ & \\
\hline FRSK & & & $\begin{array}{c}0.000 \\
(0.07)\end{array}$ & \\
\hline ERSK & & & $\begin{array}{l}0.002 \\
(2.67)^{* * * *}\end{array}$ & \\
\hline \multirow[t]{2}{*}{ TURN } & & -0.002 & -0.002 & -0.001 \\
\hline & & $(-0.47)$ & $(-0.38)$ & $(-0.18)$ \\
\hline \multirow[t]{2}{*}{ FINDEV } & & 0.006 & 0.003 & 0.007 \\
\hline & & $(0.66)$ & $(0.35)$ & $(0.72)$ \\
\hline R-squared & 0.490 & 0.502 & 0.522 & 0.470 \\
\hline F-value & $3.04 * * *$ & $2.57 * * *$ & $2.15 * * *$ & $2.23 * * *$ \\
\hline \# of cross-sections & 26 & 26 & 26 & 26 \\
\hline \# of time-series & 9 & 9 & 9 & 9 \\
\hline
\end{tabular}

Note: ***denotes $1 \%$ significance level, **denotes $5 \%$ significance level, and *denotes $10 \%$ significance level. $H C$ is literacy rate (\%) as a measure of stock of human capital, JPFDI is the log of Japanese FDI as a ratio of GDP of the host country; USFDI is the log of U.S. FDI as a ratio of GDP of the host country, DOMI is the log of the ratio of domestic capital formation to GDP, JPFDICF is the annual foreign direct investment inflow from Japan divided by the total capital formation, USFDICF is the annual foreign direct investment inflow from the U.S. divided by the total capital formation, CRISK is for country risk of host country (out of 100 points), PRSK is for political risk of host country (out of 100 points), PRISK is financial risk of host country (out of 50 points), ERSKis for economic risk of host country (out of 50 points) and FINDEV is market liquidity measure; TURN is a financial 
country, the higher the economic growth rate.

As FDI is partitioned into the part originating in the U.S. (USFDI) and the part that has Japan as the source (JPFDI), the results in table 4 show that U.S. FDI inflows are positively related to economic growth and statistically significant at the 5\% and $10 \%$ level for regression models 4.1 and 4.3, respectively, whereas Japanese FDI inflows are not statistically significant. The finding that the coefficients on USFDI are larger than the coefficients on JPFDI supports the hypothesis as developed in equation (5) that foreign investment will have stronger effect on economic growth when the capital goods brought into a recipient country are more advanced. This is consistent with the FDI theories, which posit that U.S. MNCs seek monopolistic rents from firm-specific intangible assets while Japanese MNCs do not, and simply seek for lower labor cost or natural resources (Caves and Mehra [1986] and Blonigen [1997]). It also suggests that the technology level of capital goods that Japanese FDI brings into the recipient countries during the sample period is lower than that of U.S. FDI. The coefficients of DOMI remain to be negative and significant in the model specifications 4.1 to 4.3 . However, when a different specification is used in regression 4.3 for FDI and DOMI, that is, FDI from each capital provider is divided by total capital formation in the recipient country, USFDICF and JPFDICF, the results show that U.S. FDI inflows have a greater positive impact on economic growth than Japanese FDI. As in table 3, only economic risk, ERSK, among the control variables, is a significant determinant of economic growth for the countries in the sample.

The analysis of all model specifications in tables 3 and 4 reveal strong country specific factors in explaining cross-sectional economic growth rates even after taking into account the effects associated with the independent variables. The F-values consistently allow for the rejection of the null hypothesis of no fixed effects in individual time periods that would produce correlation in the cross-sectional components of the error term. As stated above, the two-way fixed effect model for panel data used in this study has the advantage of controlling for omitted country specific factors that vary across countries, as well as for time effects that are common to all countries (Greene [2000]). ${ }^{6}$

Table 5 repeats model specification 4.4 but the sample has been

6. Only $\mu$, the overall constant and the coefficients of the explanatory variables in gi,Sxt,i from equation (11) are reported in the tables. 
TABLE 5. Relationship of Real Growth Rate of GDP, Country Sources of FDI Inflows and Other Variables in Low Income vs High Income Groups

\begin{tabular}{lcc}
\hline Variables & Low Income & High Income \\
\hline Intercept & 0.011 & 0.026 \\
JPFDICF & $(0.85)$ & $(0.10)$ \\
& 0.469 & -0.417 \\
USFDICF & $(1.57)$ & $(-0.64)$ \\
& 0.166 & 0.166 \\
HC & $(1.85)^{*}$ & $(0.98)$ \\
& -0.003 & -0.253 \\
CRISK & $(-0.02)$ & $(-0.97)$ \\
& 0.001 & 0.004 \\
TURN & $(0.70)$ & $(2.72)^{* * * *}$ \\
& 0.001 & -0.000 \\
FINDEV & $(0.11)$ & $(-0.01)$ \\
& 0.015 & -0.001 \\
R-square & $(0.72)$ & $(-0.09)$ \\
F-value & 0.609 & 0.529 \\
Number of cross-sections & $2.37 * * *$ & 1.36 \\
Number of time-series & 15 & 11 \\
\hline
\end{tabular}

Note: ***denotes $1 \%$ significance level, **denotes $5 \%$ significance level, and *denotes $10 \%$ significance level $\mathrm{HC}$ is for literacy rate (\%) as a measure of stock of human capital, $J P F D I C F$ is the Japanese FDI as a ratio of total capital formation of the host country, USFDICF is the U.S. FDI as a ratio of total capital formation of the host country, CRISK is for country risk of host country (out of 100 points), FINDEV is for market liquidity as measured by market capitalization divided by GDP, TURN is the degree of financial development as measured by value traded divided by market capitalization.

partitioned between high income group and low income group to determine whether there is a difference in the impact of FDI and other explanatory variables on economic growth. The results indicate that for low income countries, only U.S. FDI as a percentage of total capital formation (USFDICF), is a significant factor in explaining economic growth. ${ }^{7}$ This implies that the transfer of technology by U.S. MNCs to

7. In addition, to test the null hypothesis that the estimated coefficients on these variables are equal, a restricted regression was estimated (where USFDICF and JPFDICF are dropped), and the $\mathrm{R}^{2}$ from the restricted regression was used with the $\mathrm{R}^{2}$ from the unrestricted regression (regression 4.4) to generate an $\mathrm{F}$ ratio to test the null hypothesis. The $\mathrm{F}$ ratio is equal to 1.8245 , allowing us to reject the null hypothesis at the $1 \%$ level. For table 5 the estimated coefficients on USFDICF and JPFDICF in the High Income regression are not significantly different as neither is significantly different from zero. Testing this directly 
more economically disadvantaged countries has a more potent impact on their economic development. For high income countries, Japanese and U.S. FDI do not have a significant impact on economic growth. The only significant explanatory variable for the economic growth of high income countries is composite risk, CRISK. This indicates that for high income countries, the economic growth may be more closely associated with social infrastructure such as investment risk and capital market development which CRISK may be capturing.

\section{Concluding Remarks}

Consistent with earlier studies, the findings of this paper lend support to the positive role that FDI inflows from advanced countries play in facilitating the economic growth of developing countries. The findings show that the larger the proportion of foreign investment inflows relative to total capital formation, the higher the economic growth rate of developing countries. This paper finds some evidence that foreign investment will have a more potent impact on economic growth compared to domestic investment. The paper further finds that the relationship between the economic growth of the host countries and FDI inflows is stronger for U.S.-originated FDI than that of Japaneseoriginated FDI, and that the technology transfers from U.S. MNCs have an even greater impact for more economically disadvantaged countries. These findings are consistent with the notion that U.S. MNCs are more effective in generating technology transfers and spillovers to developing countries than do Japanese MNCs during the period under study.

\section{Appendix I: ICRG's Measures of Political, Economic, Financial and Composite Risk}

The Political Risk Services International Country Risk Guide (ICRG) reports measures of political, economic and financial risk. In addition, a measure of composite risk is also provided by the ICRG. This composite risk measure is a

yields an $\mathrm{F}$ ratio equal to 0.6355 , which does not permit the rejection of the null hypothesis of equality between these coefficients. The estimated coefficients on USFDICF and JPFDICF in the Low Income regression in table 5 are significantly different. Testing this directly yields an F-ratio equal to 2.7081, which permits the rejection of the null hypothesis of equality between these coefficients. 
linear function of political, economic and financial risk. The political risk index (PR) reflects 13 factors that are assigned a specific number of points ranging from 6 to 12. (ICRG has recently modified the construction of this measure to include 12 factors assigned points ranging from 4 to 12 . However, we provide the methodology relevant to the risk factors through 1997, which is the last year of our sample.) The points for each of the political factors are summed and can take on a maximum of 100 points. The financial risk index $(F R)$ is comprised of 5 factors, where each factors is assigned up to a maximum of 10 points, with a maximum summed total of 50 points. The economic risk index (ER) considers 6 factors with corresponding maximum point allocations that range from 5 to 15 , with a maximum of 50 points. The factors used to evaluate political, financial and economic risk are as follows:

\section{Political Risk}

Economic expectations versus reality (12 points)

Economic planning failures (12 points)

Political leadership (12 points)

External conflict (10 points)

Corruption in government (6 points)

Military in politics ( 6 points)

Organized religion in politics (6 points)

Law and order tradition (6 points)

Racial and national tensions (6 points)

Political terrorism (6 points)

Civil war (6 points)

Political party development (6 points)

Quality of the bureaucracy (6 points)

Total points for Political Risk (100 points)

\section{Financial Risk}

Loan default or unfavorable loan restructuring (10 points)

Delayed payment of suppliers' credits (10 points)

Repudiation of contracts by governments (10 points)

Loans from exchange controls (10 points)

Expropriation of private investments (10 points)

Total points for Financial Risk (50 points)

\section{Economic Risk}

Inflation (10 points)

Debt service as a percentage of exports of goods and services (10 points)

International liquidity ratios (5 points)

Foreign trade collection experience ( 5 points)

Current account balance as a percentage of goods and services (15 points) 
Parallel foreign exchange rate market indicators ( 5 points)

Total points for Economic Risk (50 points)

The composite risk index (CR) is determined by adding the point total of the political, financial and economic indexes and then multiplying this sum by 0.5 :

$$
C R=0.5(P R+F R+E R)
$$

The political risk measure $(P R)$ contributes 50 percent of the composite risk index $(C R)$, while the financial $(F R)$ and economic risk $(E R)$ indexes contribute 25 percent, respectively. The highest possible point value of the $C R$ index is 100 and the lowest is 0 . ICRG offers the following guidelines for interpreting the $C R$ index:

$\begin{array}{lrlr}\text { Very High Risk } & 0.0 & \text { to } & 49.5 \text { points } \\ \text { High Risk } & 50.0 & \text { to } & 59.5 \text { points } \\ \text { Moderate Risk } & 60.0 & \text { to } & 69.5 \text { points } \\ \text { Low Risk } & 70.0 & \text { to } & 79.5 \text { points } \\ \text { Very Low Risk } & 80.0 & \text { to } & 100.0 \text { points }\end{array}$

\section{Appendix II: List of Countries by Group*}

$\begin{array}{ll}\text { High Income Group } & \text { Low Income Group } \\ \text { Argentina } & \text { Bangladesh } \\ \text { Brazil } & \text { China } \\ \text { Chile } & \text { Colombia } \\ \text { Israel } & \text { Egypt } \\ \text { Korea } & \text { India } \\ \text { Malaysia } & \text { Indonesia } \\ \text { Mexico } & \text { Jamaica } \\ \text { Saudi Arabia } & \text { Nigeria } \\ \text { South Africa } & \text { Pakistan } \\ \text { Taiwan } & \text { Peru } \\ \text { Venezuela } & \text { Philippines } \\ & \text { Sri Lanka } \\ & \text { Thailand } \\ & \text { Tunisia } \\ & \text { Turkey }\end{array}$

Source: World Bank, 1997. *Low income countries are classified by the World Bank as belonging to either category 3 or 4 , while high income countries belong to either category 1 or 2 . 


\section{References}

Atje, R., and B. Jovanovic. 1993. Stock markets and development. European Economic Review: 632-640.

Barro, R., and X. Sali-i-Martin. 1995. Economic Growth. New York: McGraw-Hill.

Beck, T.; R. Levine; and N. Loayza. 2000. Finance and the sources of growth. Journal of Financial Economics 58: 261-300.

Bernstein, J., and P. Mohnen. 1998. International R\&D spillover between U.S. and Japanese R\&D intensive sectors. Journal of International Economics 44: 315-338.

Blonigen, B. A. 1997. Firm-specific assets and the link between exchange rates and foreign direct investment. American Economic Review 87 (June): 447-465.

Borensztein, E.; J. De Gregorio; and J.W. Lee. 1998. How does foreign direct investment affect economic growth, Journal of International Economics 45 (June): 115-135.

Cass, D. 1965. Optimum growth in an aggregative model of capital accumulation. Review of Economic Studies: 233-40.

Caves, R. 1971. International corporations: the industrial economies of foreign investment. Economica. (June): 1-27.

Caves, R. and S. Mehra. 1986. Entry of foreign multinationals into U.S. manufacturing industries. In Competition in Global Industries. M. Porter, (ed) Boston: Harvard Business School Press.

Clark, E. and R. Tanaru. 2001. Emerging markets: investing with political risk. Multinational Finance Journal 5: 155-173.

Coe, D. and E. Helpman. 1995. International R\&D spillovers. European Economic Review 39 (May): 859-97.

Eaton, J. and S. Kortum. 1996. Trade in ideas: patenting and productivity in the OECD. Journal of International Economics 40: 251-278.

Greene, W.H. 2000. Econometric Analysis 4th edition. Prentice-Hall, Inc.

Hall, R. and C. Jones. 1999. Why do some countries produce so much more output per worker than others? Quarterly Journal of Economics 114 (February): 83-116.

Hegazi, W. and E. Safarian. 1999. Trade, foreign direct investment, and R\&D spillover. Journal of International Business Studies 30 (Third Quarter): 491-511.

Howitt, P. 2000. Endogenous growth and cross-country income differences. American Economic Review 90 (September): 829-844.

Hymer, S. 1976. The International Operations of National Firms: A Study of Direct Foreign Investment. Cambridge, Mass: MIT Press.

IFC, Emerging Markets Data Base.

IMF. 2001. World Economic Outlook Database. http://www.imf.org

Japanese Ministry of Finance. http://www.mof.go.jp/english/

Jones, C.I. 1998. Introduction to Economic Growth. W.W. Norton \& Company, Inc. 
Kogut, B. and S. Chang. 1991. Technological capabilities and Japanese Foreign direct investment in the United States. Review of Economics and Statistics (August): 401-413.

Levine, R. 1997. Financial development and economic growth: views and agenda. Journal of Economic Literature: 688-726.

Levine, R. and D. Renelt. 1992. A sensitivity analysis of cross-country growth regressions. American Economic Review 82 (September): 942-963.

Levine, R. and S. Zervos. 1994. International capital flow liberalization and stock market development: A cross-country event study. Working paper, The World Bank.

Matyas, L. and Sevestre, P., (eds.). 1992. The Econometrics of Panel Data: Handbook of Theory and Applications. Dordrecht, The Netherlands: Kluwer Academic Publishers.

OECD. 1998. Geographical Distribution of Financial Flow to Aid Recipients.

Ozawa, T. 1972. Multinationalism, Japanese style. Columbia Journal of World Business 7: 33-44.

Perez, T. 1998. Multinational Enterprises and Technological Spillovers. Harwood Academic Publishers.

Political Risk Services. International Country Risk Guide.

Rivera-Batiz, L. and P. Romer. 1991. Economic integration and endogenous growth, Quarterly Journal of Economics 106 (May): 531-56.

Romer, P. 1990. Endogenous technological change. Journal of Political Economy 98: 71-102.

Romer, P. 1986. Increasing returns and long-run growth. Journal of Political Economy 94 (Oct): 1002-37.

Sedgwick, M. W. 1996. Does Japanese Management Travel in Asia? Managerial Technology Transfer at Japanese Multinational in Thailand. MIT Japan Program. Working paper series: 96-04.

Solow, R. M. 1956. A contribution to the theory of economic growth. Quarterly Journal of Economics: 65-94.

Stiroh, K. J. 2001. What drives productivity growth? FRBNY Economic Policy Review (March): 37-59.

UNCTAD. 1998. World Investment Report, Trends and Determinants. United Nations.

UNCTAD. 1999. World Investment Report, Trends and Determinants United Nations.

Urata, S. 1996. Japanese Foreign Direct Investment and Technology Transfer in Asia. MIT Japan Program. Working paper series: 96-23.

U.S. Department of Commerce. http://www.bea.doc.gov.

Vernon, R. 1966. International investment and international trade in the product cycle. Quarterly Journal of Economics 80: 190-207.

World Bank Policy Research Report. 1997. Private Capital Flows to Developing Countries. Oxford University Press. 